\title{
The History of Higher Education in Albania University of Tirana (1957-1960)
}

\author{
Dr. Çlirim Duro
}

\author{
Doi:10.5901/mjss.2015.v6n5s2p663
}

\section{Abstract}

Education in specific periods of social development has been treated as a priority no doubts, educational-learning activity has been one of the not substitutable elements of communication between people and progress of every civilization. It serves to the nation and every development to this field is welcomed. With termination of Second World War Albania would be faced with many difficulties, as a result of damages also of poor educational inheritance. The solution to the problems would require the active involvement of the state but also of the wide civilization of that time. a powerful influence would exercise economic, political, and social factors where no doubt the most active one remained the politic one. Communist leadership would apply totalitarian socialist system undertaking for more than five decades radical changes, with consequences in the educational development in general and the high one in special. The first decades would be defining of lying of foundations and gradually for the formation as a school category oriented toward Leninism-Marxism ideology. The end of the 50s that conformed with the opening of the first Albanian University would take a special place in this process. Within the limits of an article not pretending for exhaustive treatment, we will have a tendency toward a new approach about some of the most specific aspects of higher education performance in this period.

Keywords: Higher Education, University, Communist State

\section{The Requirements that Made Possible the Opening of the University and Its Importance}

The beginning of the 50s would mark the stage of laying foundations for the Universities. The state that was aiming the rapid industrialization remained interested in acceleration the of preparation rhythms of specialists in different fields. The extension and strengthening of the high institutions would be appreciated as the main alternative for the forward development of Albanian economy and culture.

This whole process would be supported by wide levels of population with a tendency toward a more complete education and in the same time by the social opinion that saw this as an emancipating process.

The acceleration of the extension rhythms of the higher education led to settlement of new institutions. After the two year Pedagogic Institute that marked the beginnings of the higher education in the 1951 would be opened the high four year Pedagogic Institute, the High Agricultural Institute and the Polytechnic Institute. In the 1952 would function two other Institutes, the Economic, and the Medical one followed by the Law Institute in the 1954. The extension and reorganization of the branches and the new faculties would influence positively in the growth of the number of high specialists. Gradually the entire system would reach in 6 institutes 4 and 5 years of study.

After this extension boom, the year 1957 would mark a very important moment in the performance of universities, that of the creation of the first Albanian University. The passage toward a higher shape developed in a national level would be appreciated a greater opportunity to feed the profiles extension and the settlement of new universities. After a long debate in the parties of intellectualists and state organisms and the party ones in the July of 1956 political Bureau KQ-NC (national committee) of PPSH-LPA (Labor Party of Albania) would examine the possibility of opening the State University of Tirana, September 1957 (ANA-Albanian National Archives, 511, 1956, file 22, pp. 11-12.) Obviously the communist state would precept the process from the point of view of its interests for the preparation in faster rhythms of high personnel office for the main fields of national economy and culture.

The preparations had preliminary started by department of education which in 1956 was engaged in drafting a study for undertaking such a step. The activity of the universities so far not official universities, gained experience in the organizational, educational and scientific field created opportunities for the settlement of a leading and organizational center in a national level. Such as it was projected and created the University of Tirana, the big castle of science and education, the main home to preparation and qualification of high personnel office.

The department of culture and education, in the drafted study would be discussing the necessity of settling the university, the methods of solving for providing the environments and necessary buildings, equipment, furniture and the right funds etc. Part of the study would be the future performance of Science Institute, Linguistic and History Institute as well as the Agricultural and Zoo technical matters Institutions. These last ones would be treated separately not being part 
of the university.

The proposed variant for its positioning in an appropriate place, because only in this way, except the auditoriums would have been ensured the creation of cabinets, laboratories and hall rooms for sport fields necessary for the young students would have a high financial cost. From the study of the necessities of the University for Educational Environment, laboratories and administration it resulted that they were in need of 70 auditoriums, 24 departments, 77 administration rooms and a department of $2500 \mathrm{~m}$ square distributed in faculties and specialties.

The buildings of the Science institute, Department of Education and Culture, former Physical Education School, Economic Institute, and the Party School had 111 appropriate rooms for auditoriums and departments, 65 appropriate rooms for administration and departments and $2500 \mathrm{~m} 2$ basements. Thus, from the study of needs and the condition of buildings making some adaptations it resulted that the faculties of the University could be placed in these buildings. Whereas, as a residence for the students could be used the building of the Pedagogic Institute, the dormitories of the Polytechnic Institute and the Medical one. For the necessary expenses for adaptations, bar restorations it was in need of a fund of 6.152 .000 lek (Ibid.).

In the compilation of the organics of the university the study predicted firstly the most necessary personnel to face the service needs of this important institution. As a basis served the existing organics of the high institutes and sectors of science institutes that would be involved in the university. During the study were made simplifications and necessary connections with the intention of avoiding a puffed up organics but in the same time there were predicted some appendixes that were missing in the organics of the institute. With the shortages especially in the leading staff, payment fund that would be necessary for the university administration would be lower than the fund of the payments spent for the specific administrations of high institutions altogether.

To fulfill the new needs of the university, and to provide better working conditions to the professors, most of which until this period were charged with more than one subject from the Economy Ministries, it was predicted to draw other personnel office for the university. The department would ask also to be ensured some other soviet specialists that would work by the departments, and they should have had a high pedagogic and scientific qualification, professors or (assistant professor) docents. With the opening of the university their number would reach 23 (ANA, 511, 1957, file. 4, p. 22).

Political Bureau of Central Committee of PPSH-LPA (Labor Party of Albania), in its meeting of May 15th after examined the presented study by the Education and Culture Department decided the opening of the university primarily with six faculties.

Educational programs would be drafted according to the university profile with the aim of strengthening the theoretical and special preparation between educational practices and those in production as well as would lead toward normalization of students' task. Educational programs of History-Philology and Exact Science Faculties would be drafted taking into consideration that they prepared mainly teachers (Ibid.).

According to this decision main duty of the university will be consisted in the preparation of specialist for different branches, preparation of scientific personnel office and the development and strengthening of scientific work in the most important sectors. Universities now would be the main educational center of the country therefore in it would be joined all most qualified forces of the respective field.

Within it would be incorporated all universities (except Agricultural University) as well as the Science Institute. To keep under control the educational activity and especially that of the communism education of students, the decision predicted the settlement of Party Committee with a functionary assistant and the designation of personnel office for the leading of Committee Parties (Ibid., pp. 22-28).

The University took measures to develop the scientific work in all directions and in its plans were incorporated those of Scientific Institute which would be distributed. The Institutes of Agriculture and Zoo technic matters would pass temporarily under the dependence of Agriculture Department, whereas the Hydro-Meteologic service under that of Prime Ministry.

Meanwhile, it would be worked from all the structures to create the appropriate conditions for the university staff that it could be specialized, to do scientific activities and to relate with manufacturing branches of its specialty. It is important to be appreciated the normalization of the professors charge, designating the reasonable norms and especially their insurance. All institutions were called to give the best personnel office. The placement of a new payment system it was thought to stimulate the scientific-pedagogic work taking into consideration the requirements of a university level (Ibid.).

The Presidium of Popular Assembly of Albania in June 1957 would decree the creation of the university. Taking into consideration the developments in the education field as well as would be emphasized since in the beginning of the decision and the favorable conditions created from until then work of High Institutes in basis of the orientations of II Congress of Labor Party of Albania for a following settlement of the work to prepare personnel office "...under the support 
of the article 58, point 6 of the constitution of the Popular Republic of Albania, the Popular Assembly of Albania decided the opening of the State University of Tirana. (AQSH, V. 1957, file. 31, fl. 41.)

On the basis of the Presidium decree of Popular Assembly, Prime Ministry would set the decision "About the organization of State University of Tirana". According to him, USHT-SUT (State University of Tirana) would have now six faculties: Faculty of History-Philology with two branches that of History and Philology; Law Faculty; Economic Faculty with two branches, Economy branch, and that of the Accountability Basis; Engineering Faculty with four branches, Mechanic, Electric, Mathematics-Physics and Biology-Chemistry and Medicine Faculty (Ibid. p. 38).

The institute of Zoo technic matters and Agricultural and Biology Institute "I.V.Miçurin", with the exclusion of Biology Sector which merged together with Science Institute in the State University of Tirana, they passed under the dependence of Agricultural Department, whereas the Linguistic and History Institute remained the Scientific Institute in the content of History-Philology Faculty of State University of Tirana. The Hydro-Meteologic Service passed under the direct dependence of the prime ministry. All personnel office, material and financial equipment that were in disposition, pedagogic, polytechnic, law, economic, and the medical institute as well as the science institute for the sectors that were merged in the universities, passed to the last one.

The decision for the opening of the university would be published 10th of June 1957. The biggest newspaper in the country "Zëri i Popullit" (peoples voice) date 13th of June 1957 would consider this as the most marked event in the education field. ("Zëri i Popullit", Tirana, June 13th, 1957). The education minister, Ramiz Alia in relation to this event would emphasize in his speech, that the mission of the university was "First, it would prepare his high personnel office...Secondly would give a greater development to scientific work and scientific thought in Albania in all fields. Thirdly, it would play a crucial role for the growth of existing personnel office. (Enriketa Kambo, Arsimi në Shqipëri (1945-1960), Tiranë: Mësonjëtorja, 2005, p. 165)

State University of Tirana opened the doors in September 16th, 1957. In the inauguration ceremony, the high state and party director Manush Myftiu would emphasize that it would be called the beginning date of a great undertaking and difficult to everybody. The creation of university as an integral part of a well projected state strategy fulfilled in essence the goal of higher education besides softening of the specialists requirements, fulfilled in essence the aim to preserve his classable character. Expressing clearly and without equivoques the official opinion would reconfirm that he"... would function always under the basis of principles and politics of PPSH-LPA, ideological subjects and communist education would take a very important place... idea-theoretical content of the lectures will be based in the materialistic point of view of explaining the laws and natural and social phenomena reflecting in a scientific way the practice of socialism building. ("Bashkimi" newspaper, Tirana, 16th September 1957)

With the University of Tirana that itself represented one of the most important achievements of the time would make the way for new changes. They would shine in an emphasized way in the collection of the best personnel office as well as in the comprehensive help that this great education and scientific center would give in the preparation and qualification of high personnel office necessary for the economy and culture of the country.

\section{University and Relations with Other Scientific Institutions}

The scientific activity of universities would enter a new stage with the creation of the university that affected positively in the effective concentration of educational and scientific forces especially the less studied ones. Whatsoever up to these moments it was talking about elementary modest studies. The most wide scientific activity in a state level took place in Science Institute.

In the threshold of creating the university would be opened a wide debate if in this last one would be included the Science Institute. The official opinion went toward the merge and the directors of universities would present several arguments in its favor.

According to them Science could be developed better than anywhere only in Universities because there it could be prepared the best scientific personnel office and that when it would be created the science academy it would be the best to be realized through the university. In an information from this period about the problematic that had opened the unification issued or not of these two institutions it was expressed the opinion that the importance of this process asked for "an objective analysis of the presented arguments as well as the advantages and drawbacks of the measures that would have been taken for its solution. (AQSH, 511, 1957, file. 4, pp. 1-10. From the report "Mbi shkrirjen e Institutit të Shkencave në Institutet e Larta të USHT"..)

The representatives of the Science Institute arguing their thesis would emphasize that the way to science development was mainly that of independent institutions. It was accepted that this process would enrich so far the university with personnel office of various specialties and would help the development of scientific work in several 
branches (mainly in the sciences of Philology-History and to some extent in those exact ones-Chemistry-Biology) would collect and unite scientific forces of the country as well as would strengthen the material basis etc., but always according to them in this case should have been taken into account even some other important factors. In case of unification they would really strengthen only two faculties that of History-Philology and to some extent the Faculty of Chemistry-Biology. Main Faculties of the Universities like Engineering, Medicine, Economy as well as those of Mathematics-Physics and Justice (Law) would not profit a big thing because these branches were not developed in the Science Institute.

A more tight collaboration between the two institutions would help in a better organization of the scientific work of students and would create greater opportunities for laboratory practices, expeditions and scientific leadership of works. But these results could be provided even without the merge of the science institute through scientific work combination of the scientific university personnel office. (Ibid.)

The science institute with lots of efforts had achieved to lay the basis of a systematic scientific work, wide and with a perspective. There were defined the organizational productive forms as well as it was gained a rich experience and a tradition in the scientific field. The personnel office was qualified and had raised the quality of work. Especially after the reorganization made in 1955, it had gained the physiognomy of an important central scientific institute that played a sensitive role in the development of scientific and cultural life of the country performing so far the functions of a Science Academy. The organization of several autonomous institutions and their work coordination from the Science Institute favored the acceleration process of its settlement in a near future (Ibid.). With the distribution and its structure it was thought that would be damaged the scientific work and the country would be missing a leading and coordinating center of the overall activity of this field.

According to the variant of the institute directors out of university's framework would remain important sectors as were those of Agriculture and Zoo technic matters Institute becoming this a new institution center partially of scientific work. Moreover, the organizational forms of the university were judged as inappropriate for the leading of this wide activity like the one that was held in the Scientific Institute. The organization and a good leading of it was related to various activities that is to say the coordination of scientific plans with the ministry necessities, organization in the right time of the expeditions, the discussion of completed works, the following and application of the conclusions and results of the scientific works etc.

All of these were seeking for a great commitment of leading body and hardly could be fulfilled as it should be in the framework of an institution as it was the university, where the main place was taken by educational issues.

The main university task was that of the specialists' preparation. In the high institutions none of the activities was developed detached from educational part but the first place was taken always by pedagogic activity.

This way it was in all universities of the other countries including even those of East, despite the fact that they were in the same time, centers that developed a scientific activity in a limited level. Moreover, even with a good planning of the scientific work, the practice showed that the students' preparation and the continuous improvement of the programs and the level of lectures searched for a continuous commitment that risked to be developed in the back of scientific research.

In case of the best personnel office unification of the institute sectors would dedicate most of the part and their main activity, pedagogic work and organization of faculties and departments. University as a new institution, in the first years would have to face great organizational problems and those of teaching. They were to stabilize educational plans and programs, to edit and adapt the texts and (special textbooks), to organize and equip laboratories and cabinets etc. With all these tasks, there is not enough time to make even a scientific work with a great level. The commitment in educational organizational activities of the best part of scientific personnel office would led to sensitive reduction of the activity of the these last ones in the field of science. (Ibid. pp. 22-26)

In the range of the discussed arguments would be the fact that from the university departments could not be planned complex scientific works, and with a long deadline (the drafting of a big Albanian vocabulary, the publishing of the documents, systematic study of floristic and faunistic of the country etc.), could not be realized that wide organization and complex related to the terrain, raw material, special complex apparatus, methods of study, long researches bibliographical and archival that required a scientific systematic and organized work.

Worldly experience talked that in all countries as a primary stage in the development of the science was considered the settlement of the higher educational institutions when in them "...educational work had achieved the right level and the scientific personnel office had gone forward enough, then it was felt the need for creating of independent scientific institutions for systematic studies and researches and in an organized way, in different fields of production science" (Ibid., pp. 20-22). This first stage for Albania was achieved through preparation of personnel office outside of the country and with the gained experience during work. The settlement of independent scientific institutions not related to educational sphere was considered as a second advanced stage in the science development process.

A strong argument would be considered the fact that the state for the scientific work development in a wide range, 
more than once had laid the need of the activation of wide network of external collaborators. The scientific institute with all the difficulties had reached to drag in these activities a wide range of capable personnel office of the economy and culture of the country, a process that in the University framework could bring problems. Of a special importance would be considered the gained position by the institute of science, as the only scientific institution that represents the country in the outside world performing the functions of an academy. It had now a tradition related to the relationships in this field (academy, different institutions, universities, international congresses, national libraries, different scientific) etc. which should not had been interrupted. For all these reasons the directors of the scientific institute would have been expressed against the unification idea.

After the analysis of the framework, the commission for the university creation would be expressed in favor of merging. In the presented report to high stat e structures and the party ones would be said that "...taking into consideration that the university will be the most important center of the Republic for the preparation of the high personnel office and the development of science, during the study of the university organization issue comes in front of us the need of unifying all educational and scientific forces of scientific institute of polytechnic, pedagogic, law and economic, and medicine institute and on this basis to be created the State University." This was seen as necessary measures that avoided "unnecessary parallelisms of scientific work that raised the level of educational work of the university and the scientific one in general and realized the exploitation "in a rational way of the personnel office and equipment. (ANA, P. 511, 1957, file 4, pp. 22-26. From the report "Mbi shkrirjen e Institutit të Shkencave me Institutet e Larta të USHT") .

The unification of the scientific forces in the universities was considered as a possible and beneficial process. The tasks would consist in the preparation of the necessary specialists with a high qualification for the economy and culture development, through applying into practice the science's success and creative collaboration of his scientific forces with the production employees. Within these framework, also the tasks of science institute as part of the university would find a better solution.

The commission would offer even the options of practical realization of the unification. Thus, the history branch could be merged in the Albanian History Department of the History-Philology Department. In the department of Albanian History would be settled the cabinets of the early history, middle history, new history, ethnography, medieval art, and under its dependence would be placed the ethnography museum and the archaeological one. The branch of linguistics was included in the Albanian Language Department of History-Philology Department where would be settled the cabinets of lexicology-terminology, grammar and dialectology. The chemistry laboratory merged in the chemistry branch laboratory of the exact sciences faculty and the geography sector in the department of geography of biology-chemistry faculty. The Institute of Agricultural Research, Zoo technic matters Institute as well as the Metrologic Service would pass on to Agricultural Department of State.

It was thought that the process of unification would influence positively in the elimination of unnecessary parallelisms between the two institutions, decrease the administrative expenses, and those for the settlement of laboratories, cabinets, and museums exploited in a more rational way the buildings, literature and other means for the preparation and qualification of personnel office, accelerated their growth process from the scientific part etc.

Considering unfounded the claims of the representatives of scientific institute, the commission for the university would support the official version that the scientific work center in the whole country would be university. This last one would develop scientific research work in all the knowledge fields, in basis of the approved plan in the scientific council of the university with the active participation of the state departments and institutions interested in as well as the help of social organizations. Scientific research work plan would be realized from the educational and scientific personnel of the entire system of the universities. The core of scientific work of the institute that was involved in the respective departments saved the existing organic structure.

In the universities except the scientific pedagogic personnel would have even personnel, committed mainly or entirely to the scientific research work. In this way, science institute personnel would provide greater support from educational-scientific team and from the students. Teaching lessons in the universities was considered a very important basis for the growth and scientific preparation of personnel office. One of the advantages of the merging would be considered providing of the best relations with the production and in a wider front. In the technic sciences of the engineering, mechanic, electronic, geology, construction or in the exact sciences, flora, fauna, chemistry, physics, medicine etc., the level of scientific work would be raised.

On this basis, the commission did not see any serious reason that questioned the priority of the unification always according to him, the analysis of all the factors that led to the conclusion "...that in the today's stage, as would be said in the report, the right way that creates conditions for science development and the preparation of highly qualified personnel office is the unification of the science university forces in the university that would be the highest center of science, culture and higher education in the Popular Republic of Albania." (ANA, p. 511, 1957, file 4, p. 26) In this wide front of 
scientific-research work were grown spaces for the realization of the students' diploma, aspirants' dissertations, assistants and professors.

With the creation of USHT-SUT (State University of Tirana), according to the decree of popular assembly presidium of June 1957, in its content was part the Biology Sector of the Zoo technic matters and Agricultural Institute and Biology "I.V. Miçurin" part of the science institute. The linguistic and history institute remained as Scientific Institutions in the content of the History-Philology Faculty of USH (SU) of Tirana. ("Gazeta Zyrtare", 1957, no. 9, dt. 10.08.1957, p. 306. Dekret i Presidiumit të Kuvendit Popullor të RPSH, no. 207, dt. 3.06.1957) The release of the decision that would give an end to the discussions about this issue making the way to the following deep place of scientific activity in universities.

\section{The Developments in the Organizational Field and Measures for Strengthening of the Universities}

To place over better organizational basis the entire university activity in July of 1957 , the prime minister would approve the statute of USHT (SUT). According to him, the higher education was organized on the basis of several main principles that in essence did not change from those of earlier universities. Since its first article would be defined that economic and social situation have equal rights for the university education..."In the first view seemed that there were no obstacles of economic, political, or social nature to follow the university education but in reality the later experience would prove that these rights were for everybody that fulfilled "the criteria" where the most important was the one of "political loyalty". Always according to the statute, the leading role in the development of the people culture, national by shape and socialist by content played PPSH -PPA which was helped by the professional unification, youth labor unification of Albania and other associations of laborers". (ANA, Pg. 511, Y. 1957, file 31, pp. 42-44. Decision of the Council of Ministers, No. 256, dt. 3.07.1957 "Mbi aprovimin e statutit të USHT-SUT" or Gazeta Zyrtare (On approval of the statute of USHT-SUT or Official Newspaper), no. 9, year 1957, 10th August 1957, pp. 314-330). He reconfirmed that the basic aim of USHT-SUT as well as higher institutes was "to prepare for the important branches of popular economy, science, culture, technic and health, specialists with a wide profile and high qualification", and that their main function remained "to educate under the basis of Marxism -Leninism in ideological points of view students and science pedagogic employees... to prepare scientific pedagogic personnel office capable to deal with pedagogic and scientific work, in compliance with requirements of the universities and scientific research". (Gazeta Zyrtare, 1957, no. 9, dt. 10 August 1957, fl. 314-330. Vendim i Këshillit të Ministrave, nr. 256, dt. 3 July 1957 "Mbi aprovimin e statutit të USHT".)

The statute predicted the main organisms and their activity that would explain in a wider shape, in the internal regulation of USHT-SUT and those of the faculties drafted in 1958. On their basis high schools, faculties, branches, specialties, departments, specialization courses after university, libraries, laboratories, museums etc., functioned in compliance with known principles of "socialist leading and planning" and opened and closed with decision of Prime Ministry. High school according to the regulation was run by the rector, who together with his deputies made the rectorate. In collaboration with the deans, department heads and other elements of leading administrative structures provided the application of the decisions of state and party organs for the idea-scientific and technic-professional preparation of the students, run and control the entire learning-educational work, after university qualification, the settlement of scientific-research activity, perfection and application of the plans and teaching programs etc.

For the examination of teaching-scientific and educational activity, every university settled the Science Council that was run by the rector whereas those of the faculties by the dean. It was an advisory collegial organ for all teachingscientific problems of the universities, whereas it was a decisional organ for the examination and giving the academic degree of universities and the scientific titles. Members of the council were chosen qualified educational-scientific employees of the faculties, that of other institutions as well as students representatives.

The students made $1 / 3$ of the members of scientific councils and they were elected every year by students themselves. For the examination of the publishing activity of the schools that had the right of the publishing organ functioned the publishing council that was head by the rector and at the faculties by the deans.

In the links of the higher education system and respective leading structures (rectors, deans, science councils, etc.), the department played a special role. According to the regulation of USHT-SUT, that was the basic unit of educational, teaching, and scientific work that covered one or several close subjects and was head by the department head. The main task was "healthy ideological and scientific preparation of the students".

An important place in its activity played the planning and realization of the research-scientific work, in those fields of science that covered the department and that they related with the continuous perfection of teaching quality. "It had the task to follow systematically the development of the technique and science of the country, to study and apply the best experience in the fields that belonged to and absorbed the new worldly experience to be placed in vanguard of the most 
developed scientific thought of the time in the respective theoretic fields, to create a consistent field of scientific study and research, to own and spread the most modern methods of scientific research and to reflect these achievements with a higher level in the scientific and educational work etc. (ANA. p. 511, 1958, file. 45, pg.7-15. "Rregullorja e brendshme për mësimet në USHT" - Internal regulation for lessons in USHT-SUT).

In the planning and realization process, the activity of the department was coordinated with scientific research of the respective institutions, the same departments or close of other universities as well as with the production or vital practice. For the best realization of scientific-research work, it activated except the effective members even the students, it cared for the enrichment and exploitation of basic laboratory and material and was responsible for their administration and maintenance. The drafting of the regulation and its application would place the educational-teaching process on more organized basis opening the way to a continuous development of higher education and a better fulfillment of economy requirements for specialists of different fields.

With the creation of USHT-SUT through teaching-educational work would continue to aim the preparation of high specialist in compliance with the needs of economy and culture branches, remaining the fundamental purpose of this educational category. It would be developed always more on the basis of teaching plans that defined more general relations of teaching cycles for each branch and specialty approved by the education department respecting the studies' deadlines defined by the Prime Ministry.

Their part was also the educational practice and those of production where learning had the main part. The density of learning hours and those of production was conditioned by the deadlines of completing the studies and the weekly learning task of students, these normative indicators very important that served to the process of planning in the sector of higher education.

In the branches with a 5 year deadline of studies the general number of lecture hours during the period of studies was around 4500 hours, in the branches with a 4 year and a half around 4000 hours and in the branches with a deadline 4 year around 3400 hours. (AQSH, p. 511, V. 1958, file 45, pp. 7-15. "Rregullorja e brendshme për mësimet në USHT".)

Educational plans of high school defined even the reports in between subject-groups of social-political formation and theoretic-special subjects. In the educational plans the group of social-political subjects was equal to all universities in density, order, extension. It had $10 \%$ of general density of hours in technical, exact, medicine, and agricultural sciences and around $27 \%$ in the subjects of social and economical sciences. Within them "a special" place took the direct political subjects through which the state aimed "the communist education" of high specialists. A special attention would be dedicated to reinforcement of basic theoretic subjects (mathematics, physics, chemistry etc.), that made the theoretic foundation of applied disciplines. These theoretic subjects in the engineering faculties had 20-28\% of general density of hours.

The organizational improvements realized in the entire system of higher education would serve for the deepening of the preparation process in the framework of different fields, especially in some important sectors like that of mining industry, oil, agriculture, exact sciences, medicine and education. In this framework, the council of ministers in July 1958 would decree the opening at the State University of Tirana and two new other faculties. The Oil Faculty in the preparation of engineers of drilling as well as at the 2 year Pedagogic Institute in Tirana, Physical Education Institute. For the new school year 1958-1959 in the universities would be accepted 830 new students, respectively 550 high school students, 60 from pedagogic schools and 238 from technicums (industrial schools).

For the new faculties the ministry of industry and mining undertook the insurance of the technic personnel office necessary and technic basic material meanwhile that of the education ensured the personnel for the general subjects as well as in the drafting of plans, learning text programs. (AQSH, p. 511, V.1958, file 50, fl.2. Decision of the Council of Ministers no. 239, dt. 11.07.1958 "Mbi çeljen e dy fakulteteve të reja dhe numrin e studentëve të rinj që do të provohen në vitin akademik 1958-1959") Many attempts would be made in the improvement of educational-learning process, plans, programs, theoretic and practical preparation of the students and settlement of professors' qualification. In this year would reach to be graduated 429 students, even though it should be said that compared to the developments would be noticed weaknesses that reflected in the university results. The progress of students according to the data would be 57,1 per cent marking a slight change and a raise only 0,2 per cent in report with the former period. (Ibid., 1959, file. 7, pp. 18-30. Nga informacioni i shkollave të larta mbi punën mësimore e shkencore të vitit 1958-1959.)

In these beginning results it was thought that they affect at least two factors, weaknesses in the formation of the pupils in high schools and the criteria of acceptance. Even though from year to year in higher education to drag a part of them to continue to have gaps in the subjects of general culture like mathematics, physics or language. For some subjects like those of medicine and engineering compared to high school students would be accepted mainly students of technicums (industrial schools) which developed the above subjects in a more limited density.

In these conditions they were not able to follow the lessons in many subjects of these faculties with their much 
greater efforts.

Really weak were the results in the 2 year pedagogic institutes. Even here except the others, one of the main reasons would be the level of students. Despite their importance for the preparation of teachers, in practice resulted that these institutions were given the elements that were remained after the fulfilling of needs of the universities and other 4 year high schools. They followed it not really wanting even for the fact that majority of the teachers, after the completion will work mainly in villages and remote areas of the country. Thus for example from 220 students registered in the beginning of the school year 1958-1959 in the 2 year pedagogic institute, in its end would result presented in the examinations only 172 of them. (AQSH, 511, V.1958, file. 22, p. 14. "Nga relacioni mbi rezultatet vjetore të Institutit Pedagogjik 2-vjeçar".)

Another reason of weaknesses would be that in the university the method of study changes radically and that the level and volume of the subjects was such that did not allow the same study method that would be followed in the high school. Lots of students learned mechanically the lectures which often they did not understand.

Another factor that influenced a lot in weakening the examinations results and the quality of preparation of the students would be the sensitive absence of the texts, helpful literature as well as the level of plans and educational programs. Even though periodical changes were made, there was the need of their deep place.

From a quick view of the data that had the documentation of that time would result that the educational plans and programs generally speaking remained charged with subjects of general culture meanwhile that the report with the specialty subjects was in favor of the first ones.

In the soviet schools used as a model, they varied from 12-16 per cent and in the Czech schools 10-13 per cent. In the Albanian universities they would be 19-32 per cent in USHT-SUT and 24-26 per cent in the High Agricultural Institute. The charge of students would be 36 hours for every course and the number of examinations from 5 to 7 for every semester. All these influenced in a sensitive way in the preparation and assimilation of the subjects from the students. (Kambo, Arsimi në Shqipëri.... cited., p.239) The subjects of the general culture grouped in the first and second courses led to an overload. As a consequence, majority part of students of these years showed weaknesses in these subjects. In the acquisition of important theoretic disciplines was the practical educational work and the practices in production, likely between them students understood better the laws and gained the ability to use them right. With the exception of medicine faculty for other faculties the time left for educational practices and practices in production was least. In majority part, laboratory works in this period despite the efforts did not reach to develop for the absence of equipment and the insufficient care of the departments, for the enrichment of laboratories and cabinets. (AQSH, F. 511, V. 1959, file. 7, pp. 12. "Nga relacioni mbi kontrollin e bërë në USHT", April 1959)

In general, the production practices were developed in basis of educational plans and specified programs. From a control by the Education and culture department in April 1959, in this process were noticed a lot of defects. This way for example students of Economic Faculty could not make it recognizing the problems of enterprises where they had the practice.

For their avoidance would have been tried for shortages in general subject in the size of 11-20 per cent and the increase of density of production practices. (Ibid., pp. 18-30)

The changes would affect even the field of text books. The effort for the completion generally speaking of the faculties requirements for text books were raising. Only in the educational year 1958-1959, 180 text books were multiplied with more than 30.000 pages. But it should have been said that the needs of the university and other high schools were greater. The general number of the subjects treated in the higher education system would reach 250; meanwhile that of the textbooks was not more than 104. Yet, even more problematic was presented the situation in the education without leaving work.

It was known that most of them were translations. From 100 texts in use around 80 of them were translations, 10 adaptations, and only 10 of them were originals. Moreover, as it would be mentioned in information from the Education Ministry about the performance of the year 1958-1959, "Translated text books from the corresponding soviet school books, and often did not correspond with the volume of the predicted hours in the educational plan...(Ibid.) This for sure brought difficulties to the students making it more necessary to draft the text books that were closer to Albanian reality.

Finding the evidences of the requirements always increasing for original text books in the information of a faculty that was not the only one, translations and adaptations would be considered as necessary and indispensable in the first stage of the activity of high schools. Now, they were not worth anymore as a basis for students in the real meaning of the word, but as a helpful material. It was time to be continued further that "..The drafting of original text books, refinement of the specific text books as well as any adaptation" would be treated as "first hand issue". (Ibid., file. 7, pp. 45-46. "Nga raporti mbi disa masa për përmirësimin e punës në Fakultetin Ekonomik") The entire higher education system from 1959-1960 would work on the basis of plans, programs and improved text books affecting so far in the improvement of 
the educational level process.

The developments of this period would serve to the deepening of the started processes. Significant it was the fact that despite difficulties with the opening of the university the entire high school's system would enter in the constant extension and consolidation way. In the year 1960 based in the official data, in the faculties' auditoriums would teach 6703 students respectively 3499 in the day system and 3204 in that of night correspondence. ("Anuari Statistikor", Arsimi, Tirana 1981, p. 96.)

Generally speaking the indicator would result positive in report with the starting point. The created spaces prepared the conditions for changes even the partial ones. The high institutions would offer more chances for the education of different categories of population. With all political limitations and the control of PPSH-LPA would pressure on this process, in the last level it would serve to the progress of society and preparation of the new national intelligence that contributed a lot for the country.

\section{Conclusions}

i. Among the most essential factors affecting the Albanian society of the post-war period was the political factor, as the most dominant one. Upon fully gaining political power, the communist leadership made Albania part of those countries which would apply the totalitarian socialist system. For approximately five decades, until the fall of the system in the 90s, the Albanian school would be subject to radical changes. The first two decades would be crucial in laying the foundations and consolidating higher education, as one of the important categories of the educational system, with a school oriented towards a single ideology, the Marxist-Leninist one.

ii. Developments at the University of Tirana were in line with all the changes in the Albanian educational system. However, in addition to the general features influenced by different factors of economic, political, cultural and social character, it would also manifest specific features, closely linked with its nature.

iii. The Albanian state encouraged and provided financial support for the extension of the institutions, provided scholarships for a considerable part of the students, the preparation and qualification of the teaching and academic staff, as well as the increase and improvement of the teaching and didactic materials.

iv. The year 1957 would mark a very important milestone for the process of transition from the period of laying the foundations of higher education to the establishment of a leading and organizational center of national level. The establishment of the University of Tirana would be favored by a number of factors. Firstly, from the perspective of the general economic and social development important changes had taken place. The empowered state aimed at a rapid development of the socialist economy, which would be impossible without a sufficient number of professionals. Secondly, inside the educational system in general and the higher education in particular, a lot of changes enabling the increase in the number of students had taken place. As a consequence, the institutions of higher educations would face a great number of requests for attendance..

v. The university would provide a successful solution to the preparation of specialists in the most important fields, thus filling the gaps in such strategic sectors as oil, geology, transport, etc. Until its establishment, the major part of qualified professionals belonged to social fields, followed by the fields of engineering, agriculture, economy, etc. Later, this situation would change.

vi. As regards the admission of students at the University of Tirana, the state would follow selective practices, based certain standard criteria, with the main one being selection by social origin and political attitude.

vii. The contents of the educational process at the University of Tirana would be adapted with the goals and objectives of the communist state. It would be carried out in accordance with the lesson plans, which defined the most general relationships of teaching cycles for branch and specialty. Their preparation, approval, and implementation were done by harmonizing the principle of socialist planning, i.e. that of proletarian partisanship, democratic centralization, the state-directive and scientific character.

viii. The factor of university lecturers was very active in solving complex issues regarding the Albanian school in general and the Albanian university in particular. The first professors, consisting of renowned personalities of the intellectual world, generally educated at Western universities, would be followed by the younger generation educated in the communist Eastern countries. The assessment of their work would be based on certain clichés, with the main being the level of subject adaptation with the party ideology.

ix. The analysis of the entire process of extension and consolidation of higher education in the period 1957-1960 shows that: Firstly, the pace of extension was slow due to the influence of economic, political, and social factors. Growth starts to be felt at the end of the 50s and onwards. Compared with other countries, including 
those of the Communist East, the indicators are lower. Secondly, the general tendency is quantitative increase and worse qualitative indicators, but it has to be pointed out that at the end of the period, relative improvements are observed. The obvious effects would be the insufficient level of knowledge accompanied by a weak dynamics of student progress, particularly in difficult branches and specialties such as natural sciences, engineering, agriculture, and within the higher education, both in the afternoon and part-time system. It prepared graduated specialists who were not sufficiently capable of putting theory into practice.

\title{
References
}

\author{
Archives \\ Central Archives of the Republic of Albania, three sections: \\ * Fondi i Ministrisë së Arsimit Nr. 511 \\ * Fondi i Këshillit të Ministrave Nr. 490 \\ * Fondi i Komitetit Qendror të PPSH Nr. 14
}

\section{Documentary publications}

Anuari Statistikor i RPSH, viti 1957-1968

Anuari Statistikor i vitit 1985, (Për përdorim të brendshëm), Tiranë 1985

Buletini i Institutit të Studimeve, nr.1, viti 1947

Buletini i Universitetit të Tiranës, Universiteti i Tiranës "Enver Hoxha", Shtëpia Botuese "8 Nëntori", Tiranë 1985

Dokumente Kryesore të PPSH, Vëllimi I, Tiranë 1961

Dokumente Kryesore të PPSH, Vëllimi I, Tiranë 1971

Dokumente Kryesore të PPSH, Vëllimi II, Tiranë 1971

Dokumente të organeve të larta të pushtetit revolucionar LANç (1942-1944), Tiranë 1960

Kushtetuta e RPSH, Tiranë 1946.

Ligji mbi organizimin e Sistemit Arsimor të RPSH, Kuvendi Popullor Tiranë 1963.

\section{Historical Literature}

Beqja, Hamit - Në themelet e arsimit popullor, Shtëpia Botuese e Librit Shkollor, Tiranë 1976

Beqja, Hamit- Riorganizimi i shkollës në RPSH, shtëpia Botuese "Naim Frashëri", Tiranë 1964

Dedja, Bedri - Riorganizimi i shkollës në RPSH, Tiranë, 1964

Dedja, Bedri - Shënime mbi historinë e mendimit pedagogjik shqiptar, Tiranë, 1972

Duka, Valentina - Historia e Shqipërisë 1912-2000, Tiranë: Kristalina-KH 2007

Fjalori Enciklopedik Shqiptar, vëllimi III, Botim i Akademisë së Shkencave të Shqipërisë, Tiranë, 2010

Frabboni Franco, Minerva Pinto Franca - Manuali i pedagogjisë së përgjithshme, Tiranë 2003

Golemi Bardhyl, Misja Vladimir - Zhvillimi i arsimit të lartë në Shqipëri, shtypshkronja "Mihal Duri", Tiranë, 1987

Historia e Arsimit dhe e Mendimit Pedagogjik Shqiptar, vëll.I, Botim i Institutit të Studimeve Pedagogjike, Tiranë, 2003

Historia e popullit shqiptar, Vëllimi IV, Botim i Akademisë së Shkencave të Shqipërisë, Tiranë: Toena, 2007

Historia e PPSH, Botim i Institutit të Studimeve Marksiste-Leniniste, Shtëpia Botuese "8 Nëntori" Tiranë 1981

Hunkis P Francis, Ornstein C Allan - Kurrikula: Baza, parime dhe probleme. Botim i Institutit të Studimeve Pedagogjike, Tiranë 2003

Jacques, Edwin - Shqiptarët, historia e popullit shqiptar nga lashtësia deri ne ditet tona, Tiranë: "Kartë e Pendë", 1995

Kambo, Enriketa - Arsimi në Shqipëri (1945-1960), Tiranë: Mësonjëtorja, 2005

Kazazi, Njazi - Universiteti i Shkodrës ndër vite, 1957-2002, Grup autorësh, Shkodër, 2002

Koliqi, Hajrullah - Historia e arsimit dhe mendimit pedagogjik shqiptar, Prishtinë, 2002

Kraja, Osman - Arsimi i lartë në RPSSH, para detyrash të rëndësishme, libri shkolla, Tiranë 1987

Kulla, Ndriçim - Antologji e mendimit shqiptar, 1870-1945, Tiranë, 2003

Mendimtarët për edukimin, Grup autorësh, Byroja Ndërkombëtare e edukimit UNESKO, Tiranë: Plejad, 2008

Michael, Fullain - Forca e ndryshimit të arsimit, Tiranë, 2003

Misja, Vladimir - Shndërrime në nivelin dhe strukturën arsimore të popullsisë në RPSSH, Tiranë 1963

Mulhern, James - A Histori of Education, Second etition, The Roland Press Company, New York 1959

Paçrami, Fadil - Reforma e Arsimit në Republikën Popullore të Shqipërisë, Ministria e Arsimit, Tiranë 1947

Pedagogë të mëdhenj, Grup autorësh, Tiranë: Toena, 2002

Temo, Sotir, Arsimi në Republikën Popullore Socialiste të Shqipërisë, Shtëpia Botuese "8 Nëntori", Tiranë 1984

Universiteti Shtetëror i Tiranës 1957- 1967, Tiranë 1967 
ISSN 2039-2117 (online)

ISSN 2039-9340 (print)
Mediterranean Journal of Social Sciences MCSER Publishing, Rome-Italy
Vol 6 No 5 S2 September 2015

\section{Periodical Press}

Buletini i Institutit të Studimeve, Tiranë 1947-1948

Buletini i Institutit të Shkencave, Tiranë, 1948-1951 